\title{
Practice on pressure ulcer prevention among nurses in selected public hospitals, Tigray, Ethiopia
}

\author{
Hagos Berihu', Tewolde Wubayehu², Tewolde Teklu³, Teklay Zeru and Hadgu Gerensea ${ }^{1 *}$
}

\begin{abstract}
Objectives: Pressure ulcers are localized cellular damages to the skin and underlying tissues caused by pressure, shearing and frictional force. The aim of this study is to assess practices towards pressure ulcer prevention among nurses in the Central Zone of Tigray, Ethiopia, from September 10, 2017 to June 15, 2018. This study has also identified the major barriers that hamper nurses from preventing pressure ulcers. These barriers were heavy workload, inadequate training, and lack of universal guideline and shortage of resource. $17.2 \%$ of the participants had a good practice and $82.2 \%$ of the respondents had a poor practice of pressure ulcer prevention.

Result: Finding of this study showed that respondents have inadequate knowledge which may have led to their poor practice towards pressure ulcer prevention. Immediate intervention should be done on public hospitals of central Tigray to improve nurses' practice towards pressure ulcer prevention.
\end{abstract}

Keywords: Pressure ulcer prevention, Nurse's pressure ulcer prevention practice

\section{Introduction}

Pressure ulcers are a type of injury that breaks down the skin and underlying tissue when an area of skin is placed under constant pressure for certain periods causing tissue ischemia, cessation of nutrition and oxygen supply to the tissues and eventually tissue necrosis [1]. Pressure ulcers are caused by a local breakdown of soft tissue as a result of compression between a bony prominence and an external surface [2,3]. A patient with a pressure ulcer suffers from pain and discomfort, and also may have prolonged illness, delayed rehabilitation, increased hospital stay, disability and may even face death resulting from the ulcer and its complications $[4,5]$.

A systematic review reported that the incidence rates of pressure ulcers varied considerably by clinical setting;

\footnotetext{
*Correspondence: hadgugerensea2016@gmail.com

1 School of Nursing, College of Health Sciences and Comprehensive Specialized Hospital, Aksum University, P.O.Box: 298, Tigray, Ethiopia

Full list of author information is available at the end of the article
}

ranging from 0.4 to $38 \%$ in acute care, from 2.2 to $23.9 \%$ in long term care, and from zero to $17 \%$ in home care [6].

Nurses have poor knowledge regarding risk factors of pressure ulcer development [7].World Stop Pressure Ulcer Day showed that nearly 700,000 patients were affected by pressure ulcers each year and more than 2.5 million people in the USA develops pressure ulcers each year $[8,9]$. Moreover, a worldwide health care budget that is spent on prevention and treatment of patients with extended hospital stays from pressure ulcer development amounts more than a billion dollars [10-13].

In Ethiopia, in Felegehiwot Referral Hospital, among 422 patients, the overall prevalence rate of pressure ulcers was $16.8 \%$. Of this, $62 \%, 26.8 \%$ and $2.8 \%$ developed stage I, II and stage IV pressure ulcer, respectively [14].

Major barriers that preclude nurses to practice pressure ulcer prevention (PUP) were identified with the notable ones being a heavy workload/inadequate staff, shortage of resources and inadequate training about PUP $[15,16]$. Lack of knowledge, skills, and negative attitudes towards

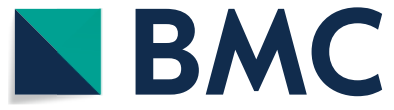

(c) The Author(s) 2020. This article is licensed under a Creative Commons Attribution 4.0 International License, which permits use, sharing, adaptation, distribution and reproduction in any medium or format, as long as you give appropriate credit to the original author(s) and the source, provide a link to the Creative Commons licence, and indicate if changes were made. The images or other third party material in this article are included in the article's Creative Commons licence, unless indicated otherwise in a credit line to the material. If material is not included in the article's Creative Commons licence and your intended use is not permitted by statutory regulation or exceeds the permitted use, you will need to obtain permission directly from the copyright holder. To view a copy of this licence, visit http://creativeco mmons.org/licenses/by/4.0/. The Creative Commons Public Domain Dedication waiver (http://creativecommons.org/publicdomain/ zero/1.0/) applies to the data made available in this article, unless otherwise stated in a credit line to the data. 
PUP contributes significantly to the occurrence or worsening of the pressure ulcer. Pressure ulcer remains a significant and complex health problem in hospitals in terms of human suffering, tissue necrosis, pain, septicemia, loss of productivity, and financial burden [17].

There is very few published paper regarding nurses' practice towards PUP in Ethiopia [18].

\section{Main text}

\section{Study area and period}

The study was conducted from September 10 to June 15, 2018, in public hospitals of Central Zone Tigray, Ethiopia.

\section{Study design}

A cross-sectional study using a quantitative method was employed in the selected public hospitals in Central Zone, Tigray, Ethiopia.

\section{Source of population}

All nurses working currently in public hospitals in Central Zone, Tigray, Ethiopia.

\section{Study population}

The study population was all nurses working in the three hospitals.

\section{Inclusion and exclusion criteria Exclusion criteria}

Nurses who are severely ill and in annual leave during the data collection period were excluded.

\section{Sample size determination}

The sample size was calculated using a single population proportion formula with consideration of the following assumptions. The proportion of the prevalence of the pressure ulcer was $16.8 \%$ which was derived from a study conducted in Ethiopia, Bahirdar Felegehiwot Referral Hospital [14]; confidence level at 95\% and marginal error of $5 \%$. The sample size was calculated as follows: the total calculated samples size was 215 . Since the total population is 240 , the sample size was determined using correction formula, and adding a $10 \%$ non-response rate and the final sample size was 125 .

\section{Sampling procedure}

There are three general public hospitals in Central Zone of Tigray. From these hospitals, study participants were selected using simple random sampling (lottery method). The list or frame of nurses working in all hospitals was obtained from the monthly work schedule prepared by the head nurse of each ward.

\section{Dependent variable}

Practice of nurses towards pressure ulcer prevention.

\section{Independent variables}

Socio-demographic factor such as

- Age

- Income

- Sex

- Knowledge of nurses

- Year of service (work experience)

- Level of education

Hospital factors such as

- Equipment

- Training guideline

Nurses' factors such as

- Heavy work load

- Lack of time

- Job satisfaction

- Patients factor (uncooperativeness)

\section{Operational definitions}

Adequate knowledge of PUP For this study, a nurse is said to have an adequate knowledge of PUP if he or she answers correctly greater than or equal to $80 \%$ of 20 pressure ulcer prevention knowledge tests.

Inadequate knowledge of PUP For this study, a nurse is said to have an inadequate knowledge of PUP if he or she answers correctly less than $80 \%$ of 20 pressure ulcer prevention knowledge test.

Good practice of PUP For this study, a nurse is said to have a good practice of PUP if he or she answers correctly greater than or equal to $80 \%$ of 20 PUP practice test.

Poor practice of PUP For this study, a nurse said to have a poor practice if he or she answers correctly less than $80 \%$ out 20 possible questions about their practices towards PUP

Perceived barriers if nurses answered "yes" or "no" with the listed barriers in the perceived barrier questionnaire.

\section{Data collection tool}

The structured questioner for knowledge and practice of pressure ulcer was adopted from a study conducted on general hospital Lahore [19] but, socio-demographic 
items were modified according the socio-cultural context of the community.

\section{Data collection procedure}

The self-administered structural questionnaire was distributed to the nurses following a request for consent from nurses and support from matrons and head nurses. Continuous follow-up and supervision were given by supervisors throughout the data collection period.

\section{Data quality assurance}

In order to maintain the quality of the data, the data collectors received training on data collection procedure. The questioner was designed carefully, and the English version was used for the actual data collection. Before the actual data collection, the questioner was checked for clarity, comprehensiveness, and content validity by pretesting on $10 \%$ of the sample size (11 nurses working in Shire Suhul hospital, Ethiopia). Finally, possible adjustments or modifications were made on the tools by the group members. Then the collected data was crosschecked for completeness and consistency each day by the principal investigators.

\section{Data process and analysis}

The data was entered, and analysis by using the statistical package for social science (SPSS) version 22 statistical software. The association between the dependent and independent variable was analyzed first in the binary logistic regression model. In the second step, predictor variable having a $\mathrm{p}$-value $<0.3$ was retained and entered to the multivariate logistic regression analysis. A p-value 0.05 was considered as cut off point for predictors to be significantly associated with outcome variables (CI-95\%).

\section{Results}

\section{Socio-demographic characteristics of the nurses}

A total of 125 professional nurses were invited to participate in the study, and the response rate was $97.6 \%$ of which the majority of the respondents (55.7\%) were females. The mean ages of the participants were 29 with the minimum age being 22 and maximum 45 years. However, the majority of them $(69.7 \%)$ were within the age group of 2029 years. More than half (53.3\%) were single whereas $45.1 \%$ of them were married and $1.6 \%$ of respondents were widowed and divorced. Regarding the educational status, the majority of them $(79.5 \%)$ were first-degree holders, while one-fifth of them (20.5\%) were diploma holders.

\section{Knowledge of nurses on pressure ulcer}

The overall nurses' knowledge of PUP was $82.75 \%$ which indicated that nurses' knowledge regarding pressure ulcer prevention was at the high level. From the study participants, 29.5\% $(\mathrm{n}=36)$ had adequate knowledge about PUP (Table 1).

\section{Nurses' practice towards pressure ulcer prevention}

From the study, $17.2 \%(\mathrm{n}=21)$ of respondents had a good practice PUP and $82.2 \%(n=101)$ of the respondents had a poor practice of PUP.

According to this finding, the nurses' practice test scores showed that $50.33 \%$ of nurses always make pressure ulcer prevention practices, $36.46 \%$ make pressure ulcer prevention practice sometimes and $15.03 \%$ never make pressure ulcer prevention practice (Table 2).

\section{Nurses' perceived barriers for practicing PUP}

Nurses were asked to indicate their agreement about the existence of specific barriers in the work environment. Among the nurses participated in the study, all of them had reported at least one of the following major challenges: heavy workload, inadequate staff, lack of universal guideline on prevention of pressure ulcer, inadequate coverage about PU during training, shortage of resources (equipment, facilities), uncooperative patients, job satisfaction in nursing, lack of time and lack of awareness.

Those who were involved in heavy workload were 2.594 (0.126-0.993) times more risky for pressure ulcer than their counterpart. Moreover, those who have knowledge were less risky $(0.354(0.126-0.993))$ than their counterpart (Table 3).

\section{Discussion}

The current findings showed that nurses who participated in the study had a good knowledge $(82.75 \%)$ towards pressure ulcer prevention which is higher than the finding of the study in Alexandria Insurance Hospitals $(<70 \%)$ with similar study participants [20] as well as the finding in a study conducted in Bangladesh (57.79\%) [13]. But, higher than the study conducted in among 3 public hospitals of AA Ethiopia (Black lion, St Paul's, Ras Desta Damtew) [21] and across 6 public hospitals (Black Lion, Zawuditu Memorial, Alert, Yekatit, Tirunesh Beijing, and Menilik II) which revealed that, the overall nurses knowledge towards PUP was $61.2 \%$ and $63.85 \%$ respectively [22]. The finding was also higher than the study conducted in Gondar University Teaching Hospital which was at $54.4 \%$ [7]. These discrepancies may occur due to a different scoring method and a different sample size.

According to this study, the highest scores of nurses' knowledge on PUP found in the educational program of pressure ulcers $(79.5 \%)$ which was less than in Ugandan nurses (92.2\%) [23]. conversely, there was a lower score of nurses' knowledge of pressure ulcer prevention. the 
Table 1 Frequency distribution of nurses' knowledge score towards pressure ulcer prevention practice in public hospitals in central zone Tigray $2018(\mathrm{~N}=122)$

\begin{tabular}{|c|c|c|c|c|}
\hline \multicolumn{5}{|l|}{ Nurses' knowledge score of pressure ulcer prevention } \\
\hline \multirow[t]{2}{*}{ Variables } & \multicolumn{2}{|c|}{ Correct } & \multicolumn{2}{|c|}{ Incorrect } \\
\hline & $\mathbf{N}$ & $\%$ & $\mathbf{N}$ & $\%$ \\
\hline \multicolumn{5}{|l|}{ Risk factors for PU development } \\
\hline $\begin{array}{l}\text { Risk factors for development of pressure ulcers are immobility, incontinence, impaired nutrition, and } \\
\text { altered level of consciousness }\end{array}$ & 113 & 92.6 & 9 & 7.4 \\
\hline Hot water and soap may dry the skin and increase the risk for pressure ulcers & 61 & 50.0 & 61 & 50.0 \\
\hline It is important to massage bony prominences & 70 & 57.4 & 52 & 35.2 \\
\hline \multicolumn{5}{|l|}{ Risk assessment for PU development } \\
\hline $\begin{array}{l}\text { All hospitalized individuals at risk for pressure ulcers should have a systematic skin inspection at least } \\
\text { daily and those in long-term care at least once a week }\end{array}$ & 82 & 67.2 & 40 & 32.8 \\
\hline The first sign of pressure ulcer development is open sore & 54 & 44.3 & 68 & 55.7 \\
\hline All individuals should be assessed on admission to a hospital for risk of pressure ulcer development & 79 & 64.8 & 43 & 35.3 \\
\hline A turning schedule should be written and placed at the bedside & 83 & 68.0 & 39 & 31.9 \\
\hline A Braden scale is risk assessment tool used for assessing pressure ulcer & 77 & 63.1 & 45 & 36.8 \\
\hline \multicolumn{5}{|l|}{ Skin care to prevent PU } \\
\hline Patient skin should be clean and dry to prevent risk of pressure ulcer development & 100 & 82.0 & 22 & 18.0 \\
\hline Persons confined to bed should be repositioned every $3 \mathrm{~h}$ & 71 & 58.2 & 51 & 40.8 \\
\hline Heel ulcer is prevented by putting pillow under the patient's leg & 91 & 74.6 & 31 & 25.4 \\
\hline A low-humidity environment may predispose a person to pressure ulcers & 65 & 53.3 & 57 & 46.7 \\
\hline $\begin{array}{l}\text { For persons who have incontinence, skin cleaning should occur at the time of soiling and at routine } \\
\text { intervals }\end{array}$ & 84 & 68.9 & 38 & 31.2 \\
\hline \multicolumn{5}{|l|}{ Nutrition to maintain healthy skin } \\
\hline Adequate dietary intake of protein and calories should be maintained during illness & 98 & 80.3 & 24 & 19.7 \\
\hline Vitamin $\mathrm{C}$ and $\mathrm{E}$ are important to maintain skin integrity & 97 & 79.5 & 25 & 20.5 \\
\hline $\begin{array}{l}\text { Serum albumin test is the appropriate laboratory test for nutritional assessment of pressure ulcer } \\
\text { patient }\end{array}$ & 72 & 59.0 & 50 & 41.0 \\
\hline \multicolumn{5}{|l|}{ Mechanical loading management } \\
\hline $\begin{array}{l}\text { The head of the bed should be maintained at the lowest degree of elevation no higher than a } 30^{\circ} \\
\text { angle consistent with medical conditions }\end{array}$ & 84 & 68.9 & 38 & 31.2 \\
\hline A person who cannot move him or herself should be repositioned every $2 \mathrm{~h}$ while sitting in a chair. & 93 & 76.2 & 29 & 23.8 \\
\hline Friction may occur when moving a person up in bed & 84 & 68.9 & 38 & 31.2 \\
\hline \multicolumn{5}{|l|}{ Educational program } \\
\hline Educational programs may reduce the incidence of PUs & 97 & 79.5 & 25 & 20.5 \\
\hline
\end{tabular}

discrepancy may be due to lack of universal training or presence of other priorities as nurses reported lack of universal guideline on prevention of pressure ulcer and presence of other priorities than pressure ulcer which may have become one of their major barrier in PU prevention. Furthermore, $17.2 \%$ of the participants had good practice regarding PUP which is consistent with the study conducted in Nigeria (27.68\%) [11]. But this figure is different from the study conducted in Gondar University Teaching Hospital [21] in which nearly half of nurses $48.4 \%$ have good practice towards PUP practice. This might be due to different evaluation tools and scoring system.
Among the practices that nurses always carry out, giving advice for the patient (69.7\%), turning patients every $2 \mathrm{~h}(71.5 \%)$ and identifying PU contributing factors $(59.0 \%)$ were the most practiced. Unlike this, a study conducted in Nigeria [11] showed that turning of patients every $2 \mathrm{~h}$ and using of special pillow to prevent PUP were the most practiced care for patients to prevent PUP. The difference between the healthcare setups of Ethiopia and Nigeria might explain the relative discrepant results in PUP practice.

The reason for the very low level of nurses' practice could be supported by Moore and Prince and study in Uganda which means that the reported nurses' barriers 
Table 2 Frequency distribution of nurses' practice score about pressure ulcer prevention in public hospitals in central zone Tigray, 2018 ( $\mathrm{N}=122)$

\begin{tabular}{|c|c|c|c|}
\hline \multirow[t]{2}{*}{ Variables } & \multicolumn{3}{|c|}{ Practice score } \\
\hline & Always (\%) & Sometimes (\%) & Never (\%) \\
\hline Observing how other nurses assess & $64(52.5)$ & $50(40.0)$ & $8(6.6)$ \\
\hline Identifying PU contributing factors & $72(59.0)$ & $42(34.4)$ & $8(6.6)$ \\
\hline Avoid dragging patients & $68(55.7)$ & $42(34.4)$ & $12(9.8)$ \\
\hline Avoid massaging bony prominences & $70(57.4)$ & $38(31.1)$ & $4(11.5)$ \\
\hline Performing skin assessment & $57(46.7)$ & $52(42.6)$ & $13(10.7)$ \\
\hline Using assessment scale & $44(36.1)$ & $68(49.2)$ & $10(14.9)$ \\
\hline Documenting all data related to PU & $58(47.5)$ & $50(41.0)$ & $14(11.5)$ \\
\hline Assess and provide pain management & $70(57.4)$ & $36(29.5)$ & $16(13.1)$ \\
\hline Providing skin care & $60(49.2)$ & $49(40.2)$ & 13(10.7) \\
\hline Placing pillow under patient leg & $66(54.1)$ & $47(38.5)$ & $9(7.4)$ \\
\hline Using or advancing care givers to use creams & $57(46.7)$ & $40(32.8)$ & $25(20.5)$ \\
\hline Paying attention to pressure points & $63(46.7)$ & $41(32.8)$ & $18(20.5)$ \\
\hline Performing lab test for nutritional assessment & $58(46.7)$ & $38(31.1)$ & $27(22.1)$ \\
\hline Providing vitamins and foods for patient & $65(53.3)$ & $37(30.3)$ & $20(16.4)$ \\
\hline Monitoring protein and calories diet & $56(45.9)$ & $49(40.2)$ & $17(13.9)$ \\
\hline Using special mattress prevent PU & $54(44.3)$ & $50(41.0)$ & $18(14.8)$ \\
\hline Turning patient every $2 \mathrm{~h}$ & $75(61.5)$ & $36(29.5)$ & $11(9.0)$ \\
\hline Using air bed for patients at high risk & $52(42.6)$ & $51(41.8)$ & $19(15.6)$ \\
\hline Attending seminars for PU prevention & $41(33.6)$ & $58(47.5)$ & $23(18.9)$ \\
\hline Giving advice for patient or care giver & $85(69.7)$ & $26(21.3)$ & $11(9.0)$ \\
\hline
\end{tabular}

may be the reasons for very low level of PU prevention. This study showed that nurses' practice almost reflected by nurses' knowledge towards PU prevention.

The heavy workload and shortage of equipment were the most reported barriers to PUP practice. This report is similar to the study conducted in Uganda in which the majority of nurses report a lack of adequate staff as a barrier for implementing effective care practice related to PUP. Similarly, the studies conducted across 6 public hospitals in AA and Gondar University also cited heavy workload as the most reported barrier to practice PUP [7]. Studies have suggested that pressure ulcer development can be directly affected by the number of nurses and the time they spent at the bedside [24].

\section{Conclusion}

- More than half of the nurses were found to have inadequate knowledge regarding PUP and

- Nurses' levels of practices were found to be very poor concerning prevention of PU.

\section{Limitation of the study}

The study was cross-sectional which didn't indicate the precedence of outcome or exposure. 
Table 3 Frequency distribution of nurses' perceived barriers to prevent pressure ulcer in public hospitals in central zone Tigray, $2018(\mathrm{~N}=122)$

\begin{tabular}{|c|c|c|c|c|}
\hline \multirow[t]{2}{*}{ Variables } & \multicolumn{2}{|c|}{ Nurses practice } & \multirow[t]{2}{*}{ COR $(95 \% \mathrm{Cl})$} & \multirow[t]{2}{*}{ AOR $(95 \% \mathrm{Cl})$} \\
\hline & Good (\%) & Poor (\%) & & \\
\hline \multicolumn{5}{|l|}{ Sex } \\
\hline Male & $8(38.1)$ & $46(45.5)$ & $1.359(0.518-3.653)$ & \\
\hline Female & $13(61.9)$ & $55(54.5)$ & & \\
\hline \multicolumn{5}{|l|}{ Age } \\
\hline $20-29$ & $15(17.6)$ & $70(82.4)$ & $1.867(0.33-10.551)$ & \\
\hline $30-39$ & $4(13.3)$ & $26(87.7)$ & $2.60(0.370-18.249)$ & \\
\hline$\geq 40$ & $2(28.6)$ & $5(71.4)$ & 1.00 & \\
\hline \multicolumn{5}{|l|}{ Income } \\
\hline Lowest & $6(32.5)$ & $10(62.5)$ & $0.273(0.081-0.919)$ & $\begin{array}{l}0.221(0.058- \\
0.840)\end{array}$ \\
\hline Medium & $5(14.3)$ & $30(85.7)$ & $0.984(0.309-3.135)$ & $0.77(0.224-2.70)$ \\
\hline Highest & $10(14.1)$ & $61(85.9)$ & 1.00 & 1.00 \\
\hline \multicolumn{5}{|c|}{ Year of experience } \\
\hline $1-4$ & $5(14.7)$ & $29(85.3)$ & $1.933(0.483-7.43)$ & \\
\hline $5-10$ & $11(16.2)$ & $57(83.8)$ & $1.727(0.520-5.737)$ & \\
\hline$\geq 10$ & $5(25)$ & $15(75)$ & 1.00 & \\
\hline \multicolumn{5}{|c|}{ Educational level } \\
\hline Diploma & $6(24)$ & $19(76)$ & $1.727(0.520-5.737)$ & \\
\hline Degree & $15(15.5)$ & $82(84.5)$ & 1.00 & \\
\hline \multicolumn{5}{|c|}{ Heavy workload } \\
\hline Yes & $13(14.6)$ & $76(85.4)$ & $1.871(0.695-5.034)$ & $\begin{array}{l}2.594(0.126- \\
0.993)\end{array}$ \\
\hline No & $8(24.2)$ & $25(75.8)$ & 1.00 & 1.00 \\
\hline \multicolumn{5}{|l|}{ Lack of time } \\
\hline Yes & $12(17.9)$ & $55(82.1)$ & $0.897(0.347-2.316)$ & \\
\hline No & $9(16.4)$ & $46(83.6)$ & 1.00 & \\
\hline \multicolumn{5}{|c|}{ Job satisfaction } \\
\hline Yes & $10(16.4)$ & $51(83.6)$ & $1.122(0.438-2.875)$ & \\
\hline No & $11(18.0)$ & $50(82.0)$ & 1.00 & \\
\hline \multicolumn{5}{|l|}{ Knowledge } \\
\hline Adequate & $10(27.8)$ & $26(72.2)$ & $2.622(0.999-6.887)$ & $\begin{array}{l}0.354(0.126- \\
0.993)\end{array}$ \\
\hline Inadequate & $11(12.8)$ & 75 (87.2) & 1.00 & 1.00 \\
\hline
\end{tabular}

Italics indicates significant association at p-value less than 0.5

\section{Abbreviations}

AOR: Adjusted odd ratio; Cl: Confidence interval; PU: Pressure ulcer; PUP: pressure ulcer prevention; SPSS: Statistical Package for Social Science; USA: United States of America.

\section{Acknowledgements}

We would like to thank all study participants and data collectors for their contribution in the success of our work.

\section{Authors' contributions}

HG: conceived and designed the study, analyzed the data and wrote the manuscript. HB, TW, TT, TZ involved in data analysis, drafting of the manuscript and advising the whole research paper. $\mathrm{HG}$ also was involved in the interpretation of the data and contributed to manuscript preparation. All authors read and approved the final manuscript.

\section{Funding}

There is no funding for this research. All cost of data collection and analysis were covered by the authors.

Availability of data and materials

The data sets used and analyzed during the current study available from the corresponding author on reasonable request.

\section{Ethics approval and consent to participate}

This study was approved by the Ethical Review Committee of Aksum University, College of Health Sciences and Comprehensive Specialized Hospital and the nurses participated in the study taken written consent after explaining the purpose, aim, objectives and the benefits of the result of this study, and they can withdraw from the study at any time if they are not comfortable. The study subjects were assured for the confidentiality of their responses. 


\section{Consent to publish \\ Not applicable.}

\section{Competing interests}

This manuscript maintains no competing financial interest declaration from any person or organization, or non-financial competing interests such as political, personal, religious, ideological, academic, intellectual, commercial or any other.

\section{Author details}

I School of Nursing, College of Health Sciences and Comprehensive Specialized Hospital, Aksum University, P.O.Box: 298, Tigray, Ethiopia. ${ }^{2}$ School of Medicine, College of Health Sciences and Comprehensive Specialized Hospital, Aksum University, Tigray, Ethiopia. ${ }^{3}$ Departement of pharmacy, College of Health Sciences and Comprehensive Specialized Hospital, Aksum University, Tigray, Ethiopia.

Received: 17 May 2019 Accepted: 30 March 2020

Published online: 10 April 2020

\section{References}

1. Bhattacharya S, Mishra RK. Pressure ulcers: current understanding and newer modalities of treatment. Indian J Plast Surg. 2015;48(1):4.

2. Grey Joseph E, Harding Keith G, Enoch S. Pressure ulcers. BMJ. 2006;332:472

3. Fogerty M, Abumrad N, Nanney L, Arbogast P, Poulose B, Barbul A. Riskfactors for pressure ulcers in acute care hospitals. Wound Repair Regen. 2008;16(1):11-8.

4. Stadelman W, Digenis A, Tobin G. Impediments to wound healing. Am J Surg. 1998;176(Suppl 2):39S-47S.

5. Jaul E. Assessment and management of pressure ulcers in the elderly. Drugs Aging. 2010;27(4):311-25.

6. Reddy M, Gill SS, Rochon PA. Preventing pressure ulcers: a systematic review. JAMA. 2006;296(8):974-84.

7. Nuru N, Zewdu F, Amsalu S, Mehretie Y. Knowledge and practice of nurses towards prevention of pressure ulcer and associated factors in Gondar University Hospital, Northwest Ethiopia. BMC Nurs. 2015;14(1):34.

8. Brindle CT, Creehan S, Black J, Zimmermann D. The VCU pressure ulcer summit. J Wound Ostomy Continence Nurs. 2015;42(4):331-7.

9. Bansal C, Scott R, Stewart D, Cockerell CJ. Decubitus ulcers: a review of the literature. Int J Dermatol. 2005;44(10):805-10.

10. Oot-Giromini B, Bidwell FC, Heller NB, Parks ML, Prebish EM, Wicks P, et al. Pressure ulcer prevention versus treatment, comparative product cost study. Adv Skin Wound Care. 1989;2(3):52-5.
11. Adegoke B, Odole A, Akindele L, Akinpelu A. Pressure ulcer prevalence among hospitalized adults in university hospitals in South-west Nigeria. Wound Pract Res Jo Aust Wound Manag Assoc. 2013;21(3):128.

12. García-Fernández FP, Pancorbo-Hidalgo PL, Agreda JJ. Predictive capacity of risk assessment scales and clinical judgment for pressure ulcers: a meta-analysis. J Wound Ostomy Continence Nurs. 2014;41(1):24-34.

13. Islam S, Sae-Sia W, Khupantavee N. Knowledge, attitude, and practice on pressure ulcer prevention among nurses in Bangladesh. In: The 2nd international conference on humanities and social sciences. 2010. p. 1-10.

14. Seid A. Assessment of self reported knowledge, practice, and barriers of diabetic foot self-care among patients attending Felege Hiwot Referral Hospital, Bahir Dar, Amhara Regional State, North West Ethiopia (Doctoral dissertation, Addis Ababa University).

15. Jzen I, Fishbein M, editors. 5. The influence of attitudes on behavior. The handbook of attitudes; 2005.

16. Lyder $\mathrm{CH}$, Ayello EA. Pressure ulcers: a patient safety issue. In: Patient safety and quality: an evidence-based handbook for nurses. Agency for Healthcare Research and Quality (US); 2008. p. 1-44.

17. Moore ZE, Patton D. Risk assessment tools for the prevention of pressure ulcers. Cochrane Database Syst Rev. 2019;1:1-24.

18. Etafa W, Argaw Z, Gemechu E, Melese B. Nurses' attitude and perceived barriers to pressure ulcer prevention. BMC Nurs. 2018;17(1):14.

19. Nasreen S, Afzal M, Sarwar H. Nurses knowledge and practices toward pressure ulcer prevention in general hospital Lahore. Age. 2017;87(166):34.4.

20. El Enein NY, Zaghloul AA. Nurses' knowledge of prevention and management of pressure ulcer at a Health Insurance Hospital in Alexandria. Int J Nurs Pract. 2011;17:262-8

21. Etafa W. Nurses KAP toward pressure ulcer prevention in Addis Ababa public hospital, Ethiopia. 2015.

22. Dilie A, Mengistu D. Assessment of nurses' knowledge, attitude, and perceived barriers to expressed pressure ulcer prevention practice in Addis Ababa government hospitals, Addis Ababa, Ethiopia, 2015. Adv Nurs. 2015;2015:1-11.

23. Mwebaza I, Katende G, Groves S, Nankumbi J. Nurses'knowledge, practices, and barriers in care of patients with pressure ulcers in a Ugandan teaching hospital. Nurs Res Pract. 2014;2014:1-10.

24. Assefa T, Mamo F, Shiferaw D. Prevalence of bed sore and its associated factors among patients admitted at Jimma University Medical Center, Jimma Zone, Southwestern Ethiopia, 2017 cross-sectional study.

\section{Publisher's Note}

Springer Nature remains neutral with regard to jurisdictional claims in published maps and institutional affiliations.

Ready to submit your research? Choose BMC and benefit from

- fast, convenient online submission

- thorough peer review by experienced researchers in your field

- rapid publication on acceptance

- support for research data, including large and complex data types

- gold Open Access which fosters wider collaboration and increased citations

- maximum visibility for your research: over 100M website views per year

At $B M C$, research is always in progress.

Learn more biomedcentral.com/submissions 